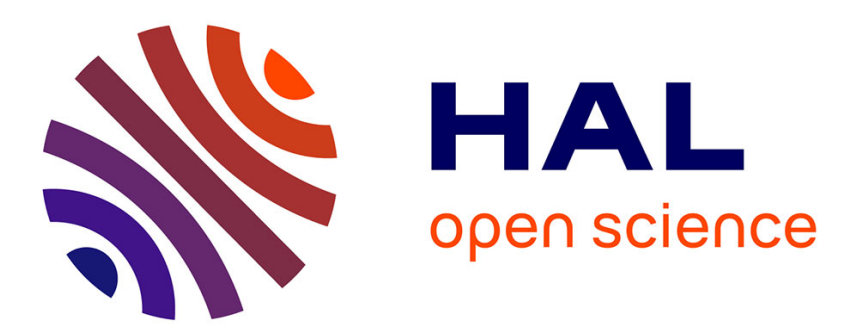

\title{
Oral and visual language are not processed in like fashion: Constraints on the products of the SOC
}

Christophe Parisse, Henri Cohen

\section{To cite this version:}

Christophe Parisse, Henri Cohen. Oral and visual language are not processed in like fashion: Constraints on the products of the SOC. Behavioral and Brain Sciences, 2002, 25 (3), pp.349-350. halshs00102695

\section{HAL Id: halshs-00102695 \\ https://shs.hal.science/halshs-00102695}

Submitted on 2 Oct 2006

HAL is a multi-disciplinary open access archive for the deposit and dissemination of scientific research documents, whether they are published or not. The documents may come from teaching and research institutions in France or abroad, or from public or private research centers.
L'archive ouverte pluridisciplinaire HAL, est destinée au dépôt et à la diffusion de documents scientifiques de niveau recherche, publiés ou non, émanant des établissements d'enseignement et de recherche français ou étrangers, des laboratoires publics ou privés. 


\title{
Oral and visual language are not processed in like fashion: Constraints on the SOC framework
}

\author{
Christophe Parisse and Henri Cohen
}

\begin{abstract}
The SOC framework does not take into account the fact that the oral modality consists of purely transient data, which is not the case for the other modalities. This, however, has important consequences on the nature of oral and written language, on language consciousness, on child language development and on the history of linguistics.
\end{abstract}

\section{MAIN TEXT}

In section 2.1, Perruchet and Vinter posit the existence of an isomorphism between 'the actual and the represented world' and explain that 'complex representations account for seemingly rule-governed behavior'. This is made possible by the existence of the Self-Organizing Consciousness (SOC), the principles of which are exemplified in PARSER. The power of PARSER was put to the test on a computer by replicating a learning situation tested with infants and adults by Saffran and collaborators (Saffran, Aslin, \& Newport, 1996; Saffran, Newport, Aslin, Tunick, \& Barrueco, 1997). The situation corresponds to the extraction of words from raw phonetic input.

The performance of PARSER is very impressive - as is that of infants and adults - but maybe not so much when one considers the characteristics of the input signal. All syllables in the input are of the same duration, the same height, share the same structure and are repeated more than a thousand times in the same situation. In such contexts, primitives such as syllable segmentation and syllable identification work so well that the problem to be solved becomes too simple and does not adequately represent real life situations. Of course, there is a lot of information other than word regularities that helps children get the job done in real life situations (see section 4.1; Perruchet \& Vinter, 1998; Johnson \& Jusczyk, 2001). Nonetheless, this affects the working context of PARSER and undermines the demonstration of Perruchet and Vinter.

A second problem is that stimuli in the oral modality ares always transient. This limits the possibility of an 'outside memory', and makes it more difficult to create an isomorphic representation. Conscious reanalysis of the signal is impossible or very constrained by our linguistic knowledge (we 'replay' the signal as we 'decoded' it, we cannot 'look at it' again), unless the words or the strings of words are repeated numerous times in the same context, which is unlikely in real life situations. One way to circumvent this limitation is through the sensori-motor loop of language production, but children do not repeat or produce all the words that they understand, so this is obviously not the only route into language structure.

However, we think that these limitations do not invalidate PARSER and the principle of SOC, if one takes into account the differences between the oral modality and other modalities. For other modalities, data are often not transient and it is possible to take full advantage of SOC to use the world as an 'outside memory' and to 'trade representation against computation'. Visual presentations and tactile sensations are much more likely than oral stimuli to lead to complex representations. Now, what is true for oral language is not true for written language. Thanks to the visual format of written language, it becomes much easier to build conscious 
representations isomorphic to the outside world. What necessitated thousands of syllables for oral language (Perruchet \& Vinter, 1998) can be accomplished with much less repetitions. This makes it easier to analyze language per se, further disconnected from its semantic interpretation, than it was for oral language.

Our proposal is that SOC works with both oral and written language, but results in different products, and that structural differences between these products have great impact on the development of language in the child and on the nature and structure of language.

The characteristics of oral language make it difficult for young children to analyze the oral signal into parts, although they are already able to understand and manipulate a great number of words. Children take actually quite a long time before being able to split into parts and to manipulate the oral forms that they used as unanalyzed wholes (Peters, 1983), and exhibit knowledge of syntactic categories (Tomasello, 2000a). However, the greater permanence of visual and tactile representations allows children to use these representations as a support for their first oral stimuli representations. This is consonant with their item-based linguistic behavior (Tomasello, 2000b) and with the importance of the semantic nature of their first linguistic knowledge. Following the pre-school years, the structure of written language becomes the outside support for internal isomorphic representations, which become in turn a support for reasoning about language. Indeed, metalinguistic thinking appears when children have learned to read, not before (Gombert, 1992).

As representations can be much more complex with written material than with oral material, real or seemingly rule-governed behavior would be much more developed in written language than in oral language. This can explain a lot about the differences between oral and written language. These differences can be found in the grammatical structures produced by native speakers (Miller \& Weinert, 1998), or in the structures and interpretations of texts and stories (Ong, 1982). Oral language tends to be more formulaic than written language and mostly composed of first-order structures. Also, oral language structures and representations are more semantic-centered than syntax-centered with a lot of, sometimes very complex, item-based constructions (see Croft, 2001), as is the case for pre-school children (Tomasello, 2000b).

Finally, in the history of the human civilizations, the meta-analysis of language always appeared after the discovery of writing (Auroux, 1994). The first written productions always were ideographic and only later became phonologic through a lengthy historical process, which eventually led to the development of the linguistic sciences (see Harris, 1980; Auroux, 1994). It seems as if a isual support was a necessary prerequisite in the detailed elaboration of the structure of the oral support and help in the transition from a purely semantic-centered view of language to a purely syntactic-centered view.

Our conclusion follows the proposal of Auroux (1994), that there are different levels of language consciousness: first, epilinguistic knowledge (the unconscious knowledge of language), which is a pure product of oral language, and, second, metalinguistic knowledge (the conscious knowledge of language), which is a by product of the use of written language. This opposition is unfortunately not yet taken into account in most linguistic and psycholinguistic theories, but could adequately be described and explained within the SOC framework.

\section{REFERENCE LIST}


Auroux, S. (1994). La révolution technologique de la grammaticalisation. Liège: Mardaga.

Croft, W. (2001). Radical construction grammar. Oxford: Oxford University Press. Press.

Gombert, J. E. (1992). Metalinguistic development. Chicago: University of Chicago

Harris, R. (1980). The language makers. London: Duckworth.

Johnson, E. K., \& Jusczyk, P. W. (2001). Word segmentation by 8-month-olds: when speech cues count more than statictics. Journal of Memory and Language, 44, 548-567.

Miller, J., \& Weinert, R. (1998). Spontaneous Spoken Language. Oxford: Clarendon Press. Methuen.

Ong, W. J. (1982). Orality and literacy : the technologizing of the word. London:

Perruchet, P., \& Vinter, A. (1998). PARSER: a model for word segmentation. Journal of Memory and Language, 39, 246-263.

Peters, A. M. (1983). The units of language acquisition. New York, NY: Cambridge University Press.

Saffran, J. R., Aslin, R. N., \& Newport, E. L. (1996). Statistical learning by 8-monthold infants. Science, 274, 1926-8.

Saffran, J. R., Newport, E. L., Aslin, R. N., Tunick, R. A., \& Barrueco, S. (1997). Incidental language learning. Psychological science, 8, 101-105.

Tomasello, M. (2000a). Do young children have adult syntactic competence? Cognition, 74, 209-253.

Tomasello, M. (2000b). The item-based nature of children's early syntactic development. Trends in cognitive sciences, 4, 156-163. 